\title{
MENEMUKAN AKAR KEGAGALAN PEMBELAJARAN BAHASA ARAB DI INDONESIA
}

\author{
Review Disertasi \\ Musykilat Tathbiq al-Manahij al-Arabiyyah fi Ta'lim al-Lughagh al- \\ Arabiyyah li al-Nathiqina bi ghairiha: Dirasah tathbiqiyyah \\ Tahliliyyah fi Ma'had Hidayat al-Najah Bekasi. \\ Tahun 2016.
}

\section{A. Perluasan Makna dan Fungsi Kebahasaan}

Tidaklah mungkin untuk dipisahkan antara agama Islam dan istilah serta Bahasa Arab. Maka, seiring dengan masuknya Islam dan tersebarnya ke berbagai pelosok Nusantara, Bahasa Arab merupakan bahasa asing yang mulai dipelajari sejak sekitar abad ke-13 M. Seiring dengan perkembangan waktu, pengajaran bahasa Arab di Indonesia kemudian mengalami beberapa perubahan dan terus dikembangkan baik dari segi metode hingga media pembelajaran.

Pengajaran Bahasa Arab kemudian mengalami pergeseran fungsi: tidak hanya terfokus pada bisa membaca al-Quran dan Hadis sebagai pedoman ajaran Islam, melainkan juga sebagai alat untuk berkomunikasi, berdiplomasi, berkegiatan ekonomi dan dikembangkan sebagai kajian akademik di lembaga pendidikan dan pusat kajian. Menurut peneliti Bahasa Arab, studi tentang pembelajaran bahasa ini terus mengalami inovasi dan perubahan sejak tahun 1880. Sekurang-kurangnya ada empat fase penting dalam perkembangan pembelajarannya. Fase pertama berlangsung antara tahun 1880-1920. Dalam fase ini, titik tekan fungsinya adalah untuk mempelajari agama, komunikasi sosial dengan tujuan penyebaran agama dan pembentukan jaringan perdagangan imigran Arab. Selanjutnya, fase kedua dari tahun 1920-1940. Bahasa Arab menjadi alat untuk untuk tukar pikiran tentang ide dan gagasan politik antikolonial. Fase berikutnya terbagi menjadi tiga periode, masing-masing periode 1940-1950, periode 1950-1960, dan periode 1960-1970. Fase keempat berlangsung antara 1970-1980. Dalam fase ketiga dan keempat tersebut, Bahasa Arab terus mengalami perluasan makna. Dari makna relijius menjadi makna ekonomis, diplomasi, internasionalisasi dan pembentukan identitas. Maka, terjadilah fungsi kebahasaan tertinggi yaitu bahasa keilmuan. 
Selaras dengan hal tersebut, maka dalam konteks pengajaran bahasa Arab berkembanglah aneka macam dan ragam variasi pendekatan dan metode pembelajaran di Indonesia. Meski perkembangan fungsi kebahasaannya meluas, tetapi penggerak utama dan awal dari hamper semua kegiatan pembelajaran Bahasa Arab masih terfokus di pesantren atau madrasah. Belum tergeres ke lembaga-lembaga yang murni bersifat pelatihan atau kajian professional, semisal Training Centre atau Universitas.

Disertasi saudara Abdullah Syubbak Muhammad Syubbak ini meneliti tentang Problematika Pembelajaran Bahasa Arab di Pesantren Hidayat an-Najah Bekasi. Jumalah halaman disertasi ini sebanyak 276. Termasuk index, glossary dan daftar pustaka.

Variasi Pendekatan, Metode dan Teknik dalam Pembelajaran

Abdullah Syubbak membagi bab dalam disertasinya menjadi lima bab. Setelah menjelaskan tentang latar belakang dan metode penelitian serta sistematika pembahasan secara kronologis, seperti lazimnya suatu disertasi, ia memulai paparannya dengan penjelasan tentang ragam metode belajar bahasa yang umumnya dapat ditemukan di Indonesia. Di samping itu ia memaparkan tentang metode pembelajaran Bahasa Arab untuk penutur asli dan untuk penutur asing. Perbedaan pokok dan karakteristiknya. Hal lain yang disampaikan juga adalah adanya beberapa kitab standard Bahasa Arab yang dikarang oleh orang Arab serta kitab rujukan Bahasa Arab yang dikarang oleh orang Indonesia serta sekilas penjelasan tentang keduanya (Bab II, hal29-90).

Menurutnya, pembelajaran bahasa Arab dan bahasa Inggris di Indonesia termasuk dalam pembelajaran bahasa asing (ajnabiyah), sebab bahasa Arab adalah bahasa yang digunakan oleh orang asing dan di luar lingkungan masayarakat. Bahasa pertama yang diperoleh oleh anak-anak Indonesia sebagian besar adalah bahasa daerah di tempat tinggal mereka. Bahasa Indonesia sendiri bagi sebagian anak-anak Indonesia adalah sebagai bahasa keduanya.

Dalam konteks Indonesia, tujuan pembelajaran Bahasa Arab sebagai bahasa asing yang diatur dalam peraturan Menteri Agama RI no. 2 Tahun 2008 tentang Standar Isi Kompetensi dan Standar Isi Pendidikan Agama Islam dan Bahasa Arab. Isi peraturan itu, diantaranya adalah (Subyakto, Nababan, 1993: 3).

1. Mengembangkan kemampuan berkomunikasi dalam bahasa Arab baik lisan maupun tulis, yang mencakup empat kecakapan 
berbahasa, yakni menyimak (istima), berbicara (kalam), membaca (qira'ah) dan menulis (kitabah).

2. Menumbuhkan kesadaran tentang pentingnya bahsa Arab sebagai salah satu bahsa asing untuk menjadi alat utama belajar, khususnya dalam mengkaji sumber-sumber ajaran Islam.

3. Mengembangkan pemahaman tantang saling keterkaitannya antara bahasa dan budaya serta memperluas cakrawala budaya. Dengan demikian peserta didik diharapkan memiliki wawasan lintas budaya dan melibatkan diri dalam kereagaman budaya.

Dari tujuan pembelajaran di atas dapat dipahami bahwa Bahasa Arab merupakan bahasa asing sehingga dalam pembelajaraanya menggunakan sistem pembelajaran bahasa asing, baik dari tujuan, metode dan media. Dalam pembelajaran Bahasa Arab terdapat tiga istilah yang saling berkaitan satu sama lain yaitu: pendekatan (alMadkhal/Approach), metode (at-Tariqah/Method) dan teknik (alUslub/technique).

Pembedaan antara pendekatan, metode dan teknis adalah pendekatan dimaknai sebagai seperangkat asumsi yuang berkenaan dengan hakikat bahasa dan belajar-mengajar bahasa. Pendekatan merupakan landasan filosofis yang digunakan sebagai acuan agar pembelajaran dapat berjalan dengan baik sesuai dengan kebutuhan dan kemampuan peserta didik. Pendekatan lebih bersifat filosofis dan sketsa perencanaan. Sedangkan metode adalah rencana menyeluruh penyajian bahasa secara sistematis dan tidak bertentangan dengan pendekatan. Ia kelanjutan dari konkretisasi dari sketsa tersebut dan penerjemahannya menjadi langkah yang operasional. Dengan kata lain, bahwa metode adalah langkah-langkah yang digunakan menerapkan teori di dalam kelas dan bersifat prosedural. Adapun teknik lebih bersifat aplikatif dan sering disebut dengan gaya pembelajaran. Teknik dapat juga dimaknai sebagai seni penerapan dan kontekstualisasi pendekatan dan metode dalam langkah yang nyata serta beradaptasi secara situasional.

Pendekatan, metode dan teknik dipandang sebagai sebuah sistem yang saling berkaitan satu sama lain. Dengan kata lain, pendekatan akan melahirkan metode-metode, dan metode akan melahirkan teknik-teknik. Misalnya, dalam pembelajaran bahasa ada pendirian bahwa bahasa lahir dari segala sesuatu yang didengar dan diucapkan, sehingga dalam pembelajaran bahasa yang pertama kali dilakukan adalah dengan menanamkan kemampuan menyimak (alIstima) lalu kemampuan berbicara (al-kalam), sebab kemampuan 
membaca dan menulis (maharat al-kitabah wa al-qira'ah) akan hadir setelahnya. Pendekatan yang digunakan tersebut kemudian akan memunculkan metode apakah yang tepat untuk meningkatkan kemampuan menyimak dan berbicara, sehingga kemudian metode yang digunakan akan menampilkan teknik yang dilakukan oleh pengajar di dalam kelas (Habibah, 2016: 25-34: Hermawan, 2011; 57).

Kemampuan menyimak dan berbicara merupakan kemampuan keterampilan (maharat) dalam pembelajaran bahasa. Dalam keterampilan menyimak dan berbicara, metode yang sering digunakan adalah metode audiolingual. Metode audiolongual digunakan untuk melatih pelajar bahasa asing secara cepat. Metode audiolingual juga menekankan pada metode drill yaitu latihan berkali-kali untuk memaksa para pelajar mengulang dan merucapkan pola kata atau kosakata yang diberikan oleh guru secara berulang-ulang dengan baik tanpa kesalahan.

Metode drill berkaitan erat dengan teori behaviorisme yang menekankan pada sebuah pembiasaan yang dilakukan secara berulangulang agar membentuk sebuah jawaban (response) dari rangsangan (stimulus) yang diberikan oleh guru. Metode ini dianggap baik dan sesuai dalam pembelajaran bahasa, sebab dengan sebuah pengulangan yang dilakukan secara terus menerus maka pelajar bahasa akan terbiasa dengan apa yang ia dengar dan ucapakan.

Menurut Albert Scholz kemampuan bebicara menjadi penentu apakah seseorang yang belajar bahsa asing telah dikatakan berhasil atau tidak. Sebagai contoh, seorang guru bertanya kepada siswa yang telah menyelesaikan studinya di Inggris selama empat tahun, mempelajari bahasa Italia selama tiga tahun, dan bahasa Spanyol selama dua tahun, akan tetapi ia tidak bisa berbicara satu bahasapun dari bahasa yang telah dipelajarinya tersebut. Maka, sangat wajar jika kemudian gurunya menyimpulkan, jika belajar bahasa asing hanya mengandalkan teori yang diberikan di kelas tidak akan dapat menjadikan pelajar mampu berbahasa asing, sehingga melatih berbicara siswa adalah bagian terpenting dalam pembelajaran bahasa. Sebab kemampuan menulis dan membaca akan berjalan seiring kemampuan berbicara (Habibah, 2016: 25-34: Scholz, 1945: 688-692).

Ahli pembelajaran bahasa Samir Yunus Shalah dan Sa'ad Muhammad al-Rushdi menyatakan bahwa dengan menerapkan kemampuan berbiacara kepada anak dalam pembelajaran basaha asing, maka akan memperkaya pengetahuan mereka dalam kosakata dan 
susunan kalimat. Selanjutnya, melatih pelajar untuk berbicara bahasa asing juga menyebabkan otak anak lebih cepat dalam berfikir dan menyusun kalimat (Habibah 2016: 25-34: Shalah, Rushdi 1999: 146).

Keterampilan berbicara lazimnya menjadi fokus penting yang harus diterapkan dengan benar oleh pengajar bahasa asing. Pendekatan yang digunakan tersebut diasumsikan pada keyakinan bahwa kemampuan berbahasa seseorang terlihat dari bagaimana ia mampu berbicara dengan bahasa asing yang telah ia pelajari. Pengajar bahasa asing harus benar-benar paham bahwa tujuan tersebut harus disesuaikan dengan metode yang akan diberikan kepada peserta didik. Pengajar bahasa harus mengerti bahwa mengajarkan bahasa asing kepada peserta didik tidak sama dengan mengajar mata pelajaran lain. Belajar bahasa asing memiliki pola dan gaya khusus. Harus dilakukan secara berulang-ulang dengan pol latihan (drill) sampai benar-benar lancar dan tidak ada kesalahan. Siswa harus terbiasa mendengar kalimat yang akan diucapkan sehingga otak akan terangsang untuk mengikuti.

Metode drill yang digunakan dalam pembelajaran bahasa dianggap cukup efektif dan erat hubungannya dengan teori behaviorisme. Belajar bahasa tidak hanya berkaitan dengan kemampuan bawaan sejak lahir (Language Acquisition Device/Jihaz iktisab al-lugah). Sebab meskipun seseorang memiliki kemampuan bawaan lahir (innate ability) namun jika tidak dilatih dan tidak dibiasakan maka LAD tidak akan berfungsi sebagai alat yang mempengaruhi kemampuan berbahasa seseorang. Para pelajar tetap memerlukan sebuah pengawasan sebagai penguatan apakah kalimat yan ia ucapkan benar atau salah. Seorang anak yang pertama kali berbiaca, berawal dari apa yang ia dengar dari lingkungannya, artikulasi yang kurang jelas atau kurang tepat kemudian mendapat penguatan dari keluarga sehingga anak akan mengulang untuk mengucapkan kembali kalimat yang sama seperti yang ia dengar. Proses pemerolehan bahasa pertama pada anak tersebut memiliki persamaan dengan pembelajaran pada bahasa kedua atau bahasa asing, bahwa untuk dapat berbahasa maka seseorang harus berbicara. Setidaknya ini menjadi madzhab dominan. Khususnya bagi mereka yang menekankan aspek keaktifan berbahasa.

Metode "berbicara" dalam pembalajaran bahasa juga disetuji oleh Wm.H Carpenter, yang menyatakan bahwa untuk dapat berbahasa maka seseorang harus bersikap layaknya anak kecil saat memperoleh 
pertama kali bahasa pertamanya yaitu berbicara meskipun salah. Metode ini dianggap lebih cepat dan meyakinkan dalam pembelajaran bahasa kedua sebab menurut Carpenter bahwa bahasa dan kesadaran adalah dua hal yan tumbuh secara bersamaan, sehingga menurutnya untuk bisa berbahasa maka berbicaralah layaknya anak kecil yang pertama kali memperoleh bahasa ibunya. Metode ini disebut metode "natural" yaitu metode berbahasa tanpa menggunakan kaidah dan tata cara berbahasa (Hamidah, 2016: 25-34: Carpenter 2015: 611-615).

Kemampuan berbicara (maharat kalam) akan menjadi faktor keberhasilan dalam pembelajaran bahasa kedua, dengan berbicara menggunakan bahasa yang sedang dipelajari maka seseorang dikatakan telah mampu berbahasa asing meskipun kalimat yang dikatakan tidak selalau benar. Seperti metode "Natural" oleh Carpenter yang juga disetuji oleh Chas W. Super. Menurutnya, siapapun yang ingu belajar bahasa baik anak-anak ataupun orang tua, maka ia harus melatih lidahnya untuk berbicara.

Hug Mehan juga menyatakan bahwa ketidaksinambungan interaksi yang terjadi antara di sekolah dan di rumah menjadi salah satu kesulitan bagi siswa Amerika dalam belajar bahasa asing. sebabnya adalah ketiadaan komunikasi baik verbal maupun non verbal. Mereka hanya menerima pengetahuan linguistik di kelas namun tidak mendapatkan sebuah lingkungan yang diciptakan khusus untuk membudayakan bahasa yang sedang dipelajari. Itulah mengapa lingkungan lebih mempengaruhi kemampuan berbahasa seseorang dari pada innate ability (LAD) dalam pemerolehan bahasa pertama atau dalam pembelajaran bahasa kedua (Habibah, 2016, 25-34: Mehan 1984, 174-178).

Selanjutnya selain metode audiolingual, metode yang tepat dan umum digunakan dalm pembelajaran bahasa Arab di Indonesia adalam metode langsung (At-Tariqah al-mubashirah/ Direct method). Metode langsung muncul sebagai sebab atas ketidakpuasan terhadap metode tata bahasa dan terjemah. Namun meskipun metode langsung merupakan ketidakpuasan terhadap metode tata bahasa dan terjemah. Metode langsung baru mulai digunakan pada tahun 1920an. Metode ini dikembangkan atas dasar asumsi bahwa proses belajar bahasa asing atau bahasa kedua sama dengan belajar bahasa ibu, yaitu dengan penggunaan bahasa secara langsung dan intensif dengan berkomunikasi, menyimak dan berbicara. Sehingga dalam 
pembelajaraanya, siswa akan diajak secara langsung untuk berbicara seperti layaknya pertama kali berbahasa ibu di rumah.

Belajar bahasa asing dengan metode langsung lebih menekankan pada keterampilan menyimak dan berbicara (al-istima wa al-kalam), dalam penggunaan metode langsung para pelajar tidak diperbolehkan untuk menggunakan bahasa ibunya sama sekali, metode ini dilakukan agar pelajar terbiasa dengan bahasa yang sedang dipelajari. Metode ini lebih menekankan pada bagaimana para pelajar pandai menggunakan bahsa yang sedang dipelajari sehingga penggunaan tata bahasa dan penghafalan kaidah tidak di tekankan dalam metode ini. Asumsi terseebut menilai bahwa belajar bahsa adalah untuk dapat berbicara dan berkomunikasi seperti layaknya penutur asli (native speaker). Nashruddin bouhsain juga mengatakan, bahwa metode langsung merupakan alternatif tepat dalam pembelajaran bahasa asing sebab metode ini lebih ditekankan pada keterampilan berbicara. Teknik yang digunakan dalam metode langsung adalah pengajar bahasa memberikan dialog-dialog pendek yang umum digunakan dalam percakapan sehari-hari secara berulangulang, kemudian para siswa diminta untuk mengulang dan melakukan dialog bersama temannya secara bergantian. Pemberian tata bahasa tidak mengacu pada analisa nahwu melainkan langsung memnberikan contoh-contoh secara lisan sehingga mengajak siswa untuk lebih mudah dalam memahami kaidah dengan pemberian contoh tanpa harus menghafalkan kaidah.

Penggunaan metode yang tepat dalam pembelajaran bahasa akan membantu siswa unhtuk mahir berbahasa, sebaliknya metode yang tidak tepat akan mengakibatkan pembelajaran tidak berlangsung dengan baik dan tujuan pembelajaran tidak tercapai. Kesalahan tersebut bisa disebabkan oelh kehendak guru yang mengabaikan kebutuhan peserta didik atau fasilitas dan situasi kelas yang tidak mendukung, sehingga penggunaan pendekatan, metode dan teknik dalam pembelajaran bahasa sangat menentukan keberhasilan siswa dalam berbahasa asing.

Menurut Abdul Aziz bin Muhammad al-Harabi, Abdullah bin Muhammad al-Shari dan Abdul Aziz Sa'ad al-Khaslan, bahwa pengajar yang baik dan profesional adalah pengajar yang memahami materi dengan baik, menggunakan metode yang tepat dalam pengajaran dan seseorang yang mahir dalam bidangnya. Ketentuan tersebut merupakan ukuran standar bagi seorang pengajar yang ingin

INDO-ISLAMIKA, Volume 6 No.1 Januari - Juni 2016/1438 I 173 
mencapai tujuan pembelajaran. Seorang pengajar harus bersikap profesional dalam mengajar, sebab keprofesionalitasan seorang pengajar merupakan hal yang sangat penting dan menjadi penentu keberhasilan siswa dalam memahami materi.

Langkah yang dilakukan untuk mengetahui apakaah metode yang digunakan berhasil atau tidak maka dapat dilihat dengan melakukan evaluasi pada akhir pembelajaran dengan memberikan bebereapa pelatihan berupa pertanyaan langsung kepada pserta didik. Langkah ini dilakukan untuk mengetahui sejauh mana pemahaman mereka terhadap materi. Evaluasi yang dilakukan sebaliknya dengan langsung bertanya secara lisan kepada para siswa, misalnya mengajak berdialog dengan menanyakan materi yang telah dipelajari. Cara ini berfungsi untuk mengukur apakah metode yang digunakan telah berhasil atau tidak dan apakah metode tersebut cukupo baik dalam memberikan pemahaman kepada peserta didik.

Suasana dan hal yang demikianlah yang ditemukan Syubbak dalam studinya ini. Teori, metode dan praktik yang demikian menurutnya menenggelamkan para siswa dalam habitat asli kebahasaan. Membiasakan mereka berada dalam suasana kebahasaan seperti lazimnya penutur asli bahasa tersebut. Model pendekatan yang demikian berarti menggunakan cara belajar bahasa asing, seperti penutur asli belajar bahasa asal dan bahasa aslinya. Jadi, ini berarti tidak terlalu fokus pada pembedaan antara belajar bahasa asli bagi penutur asli maupun belajar bahasa asing bagi penutur asing.

Ringkasnya, dapat disimpulkan bahwa dari sisi teori pembelajaran bahasa, secara umum terdapat dua pandangan yang berkembang selama ini. pandangan pertama mengacu pada ide-ide yang digagas oleh Leonard Bloomfield dan kawan-kawan yang menganalisis bahasa sebagai sebuah struktur yang nampak dan bisa diamati, jauh dari pengaruh pikiran, tebakan, firasat dan intuisi yang tidak dapat diamati.

Pandangan pertama ini kemudian ditindak lanjuti oelh Skinner melalui teori behaviorisme dalam belajar bahasa. Dari hasil percpbaannya, Skinner berkesimpulan bahwa perilaku berbahasa dapat dilakukan dengan cara penguatan. Penguatan ini terjadi melalui dua proses yang disebuit stimulus dan respon. Hal ini menuntut pengulangan stimulus dalam bentuk respon. Lebih lanjut Skinner menegaskan bahwa proses belajar bahasa akan berlangsung dengan baik apabila respon diulangi secara tepat. 
Sementara itu, pandangan kedua dalam pembelajaran bahasa muncul sebagai imbas dari gagasan Chomsky tentang lingustik generatif transformatif. Pandangan ini menekankan bahwa bahasa manusia tidak bisa diteliti semata-mata dalam lingkup stimulus dan respon yang tampak atau hanya berdasarkan pada data mentah yang dihimpun oleh para peneliti lapangan (Saepul Islam, 2015: 19-21). Lebih lanjut Chomsky menyebutkan adanya pengaruh aspek lahiriah dalam kemampuan pemerolehan bahasa seseorang sejak dilahirkan. Aspek ini dikenal dengan Language Acquisition Device(LAD).

\section{B. Akar Kegagalan}

Disertasi ini terfokus untuk mengungkap beberapa metode yang dianggap salah dalam proses pembelajaran. Beberapa kesalahan utama yang ditemukan dalam disertasi ini intinya terpusat pada bahwa metode pembelajaran Bahasa Arab untuk orang asing tidak dapat disamakan dengan metode pembelajaran untuk penutur aslinya (Bab IV, hal. 155-254).

Kegagalan dan kesulitan utama dalam pembelajaran Bahasa Arab di Pesantren Hidayat al-Najah menurut penulis, berpangkal pada penggunaan metode belajar bahasa asing yang diterapkan tanpa adaptasi dan modifikasi. Hal ini berarti, menyamakan proses belajar bahasa untuk semua orang: penutur asli maupun orang asing. Bagi penulis, jika tidak dirubah pola pendekatan ini, maka akan terus mengakibatkan kegagalan.

Penulis mencoba untuk menggunakan alat pengukuran efektivitas pembelajaran berdasarkan pada pendekatan kuantitatif melalui Statistical Package for Social Sciences (SPSS). Dimensi yang diukur dilihat dari murid dan peserta didik serta guru. Hal ini meliputi aspek: aktivitas kebahasaan, buku referensi pembelajaran, pendekatan pensyakalan dalam belajar, proses dan metode belajar.

Sayang sekali, dalam mengukur semua aspek di atas, penulis kurang memberikan tafsir dan analisis yang bersifat kualitatif sebagai penguat dari ukuran kuantitatif. Angka-angka yang ditemukan seolah dibiarkan 'telanjang' tanpa ada elaborasi lebih jauh. Sehingga, kesimpulan yang diambil di akhir pembahasan dan disertasi masih terasa kering dan meloncat (Bab V, hal. 255-256).

Karena tidak dikuatkan dengan uji kualitatif itulah maka kesimpulan penelitian akhirnya terjebak pada proses pemukulrataan (overgeneralisasi). Tidak ada ukuran apa yang dimaksud dengan 
kegagalan dan sejauhmana itu terkonfirmasi secara empiris-kualitatif. Tidak dilihat misalnya, berapa banyak alumni pesantren tersebut yang ternyata sukses dalam pengembangan kemampuan dan ketrampilan kebahasaannya. Yang bersangkutan misalnya mampu melanjutkan belajarnya ke jenjang yang lebih tinggi dengan kuliah di negara penutur asli di universitas terkemuka. Atau alumni pesantren yang terjun dalam kegiatan kemasyarakatan, ternyata diakui kompetensi keagamaannya dan dianggap mumpuni ilmu keagamaannya karena memiliki ilmu alat (kebahasaan) yang baik. Aspek ini tidak secara nyata terkonfirmasi dan diuji oleh peneliti.

Last but not least, sampai sekarang, model pembelajaran bahasa asing yang dijalankan semisal di Pesantren Hidayat al-Najah ini terjadi di banyak lembaga pendidikan. Alumninyapun menyebar di berbagai tempat dan profesi. Dari yang menjalankan profesi sebagai tokoh agama, diplomat, pedagang, pengusaha, penterjemah sampai birokrat. Menyebarnya mereka di berbagai profesi tersebut dapat diartikan sebagai tolok ukur keberhasilan. Jadi, sekali lagi, sulit untuk menyatakan bahwa sudah terjadi kegagalan total dikarenakan salah penggunaan metode pembelajaran.

\section{DAFTAR PUSTAKA}

Abdul Hadi Buthalib, Ta’lim wa Taállum al-lughah al-Arabiyyah wa tsaqafatuha (Maghrib: Arabian al-Hilal, 1991).

Abid Taufiq al-Hashimi, al-Muwajjah al-Ámali li Mudarris al-Lughah al-'Arabiyyah (Beirut; Muassasah al-Risalah, 1983).

Acep Hermawan, Metodologi Pembelajaran Bahasa Arab (Bandung: Remaja Rosydakarya, 2011)

Albert Scholz, "A Method of Teaching Modern Languages", The Modern Language Journal, Vol. 29, No. 8, Des 1945.

Christine U Grosse, "The Foreign Language Method Course", The Modern Language Journal, Vol. 77, No. 3, Autumn, 1993.

Asep M Saepul Islam, Dekonstruksi dan Demotivasi Pembelajaran Bahasa Arab (Bandung: Pustaka Aura Semesta, 2015)

Hasan Mardi, al-Lughagh wa al-Tafkir (Beirut: Dar al-Fikr, 1994).

James R. Hurford, Nativist and Functional Explanations in Language Acquisition (Dordrecht-Holland: Foris Publication, 1990). 


\section{Mempertimbangkan Kembali Hubungan Islam dan Ilmu Pengetahuan}

Noam Chomsky, On Nature and Language (Cambridge Univ. Press, 2002).

-----, Language and Problem of Knowledge (London: The MIT Press, 1997).

Nur Habibah, Lingkungan Artifisial Dalam Pembelajaran Bahasa Arab (Ciputat: Cinta Buku Media, 2016).

Rod Ellis, Understanding Second Language Acquisition (New York: Oxford Univ. Press, 1985).

(JM Muslimin) 